\title{
New age constraints on the tectogenesis of the Kheis Subprovince and the evolution of the eastern Namaqua Province
}

\author{
H.F.G. Moen \\ Council for Geoscience, P.O Box 775, Upington 8800, South Africa \\ e-mail: gmoen@lantic.net \\ R.A. Armstrong \\ Research School of Earth Sciences, The Australian National University, Canberra, ACT 0200, Australia \\ e-mail: richard.armstrong@prise.anu.edu.au
}

(c) 2008 March Geological Society of South Africa

\begin{abstract}
Mapping and stratigraphic analysis of the rocks adjacent to the Kaapvaal Craton east of Upington has suggested that the area previously defined as the Kheis Subprovince was deformed and metamorphosed not during the so-called Eburnean "Kheis Orogeny" but as the result of a considerably younger event. U-Pb zircon SHRIMP ages on sedimentary as well as volcanic and plutonic rocks show that the arenitic successions that dominate the area were derived from a provenance similar in geochronological make-up to the Kaapvaal Craton and laid down no earlier than $\sim 1.8$ Ga ago. Deposition of the volcanosedimentary Wilgenhoutsdrif Group is dated at $\sim 1.3 \mathrm{Ga}$, confirming its unconformable relationship to the arenites and its co-magmatic relationship with the similarly-aged Kalkwerf Gneiss. The regional dynamothermal event is concluded to be early Namaquan, and its age is revealed by its post-Wilgenhoutsdrif character and Rb-Sr muscovite ages clustering around $\sim 1.2 \mathrm{Ga}$. These findings confirm that the Kheis Subprovince contains no Eburnean orogenic signature and is, in fact, an integral part of the Namaqua Province. The post-tectonic Koras Group lies entirely within the subprovince and its $<\sim 1.17 \mathrm{Ga}$ age is consistent with the area's early Namaquan tectonic signature. It is separated from the $\sim 1.1$ to $1.0 \mathrm{Ga}$ old Gordonia Subprovince by the Trooilapspan shear zone, a terrane boundary thought to indicate significant lateral displacement.
\end{abstract}

\section{Introduction}

The Precambrian crustal architecture of South Africa is dominated by two distinct domains, the Kaapvaal Craton and the Namaqua-Natal Province (Figure 1). The former is characterised by $>\sim 2.6 \mathrm{Ga}$ crystalline basement, including Archaean granite-greenstone terranes, and undeformed to mildly deformed Palaeoproterozoic cover successions. The Namaqua-Natal Province forms an arcuate belt around the southern and western parts of the Kaapvaal Craton, and consists of highly deformed and metamorphosed supracrustal successions, layered gneisses and voluminous granitoid plutons which came into being as a result of the Mesoproterozoic (Kibaran) Namaqua tectonothermal event. Its southern boundary, obscured by Phanerozoic cover, is generally believed to be marked by the Southern Cape Conductive Belt (De Beer and Meyer, 1984; Du Plessis and Thomas, 1991).

The interface between the Namaqua-Natal Province and the Kaapvaal Craton is exposed only in northern KwaZulu/Natal and the Northern Cape Province. In KwaZulu/Natal, northward obduction of Namaqua rocks onto the craton was established through the work of Matthews (1972), Thomas et al. (1994) and others. In the Northern Cape, however, the situation is complicated by the fact that $\sim 1.2$ to $1.0 \mathrm{Ga}$ Namaqua crust is separated from the Kaapvaal Craton by a belt of highly deformed, low-grade arenites and semipelites which seem to be contiguous with mildly deformed, terrigenous and fluvial arenites of the Palaeoproterozoic
Olifantshoek Supergroup. This $\sim 1.9$ Ga old succession (Cornell et al., 1989) overlies the Kaapvaal Craton with a regional unconformity.

The crustal segment between the Kaapvaal Craton and the Namaqua front (Vajner 1974a) is structurally and stratigraphically distinct and was termed the Kheis Province by Blignault et al. (1974). Subsequent researchers have referred to this area as a "Belt", "Domain", "Province" or "Subprovince", and various eastern and western boundaries have been proposed (e.g. Vajner, 1974b; Stowe, 1983; Hartnady et al., 1985; Thomas et al., 1994). These different terminologies and boundaries reflect the differing views regarding the ages ascribed to the deposition and deformation of the constituent lithological units and their stratigraphic relationship to the cover sequences of the Kaapvaal Craton and the Namaqua Province sensu stricto.

Vajner (1974b) regarded rocks of his "Kheis Group" (now known as the Brulpan Group) and their early deformation as Archaean, and therefore excluded the Olifantshoek Supergroup from his tectonic Kheis "Domain". He described the mutual contact as a major fault and discounted any direct correlation between the Brulpan and Olifantshoek successions on account of "...marked differences in lithology, structure and metamorphism of the two major units". Later authors, citing a conformable contact between these successions, expanded the Kheis "Province/Subprovince" eastwards to include the Olifantshoek Supergroup. Botha et al. (1977), for example, regarded the early deformation in 


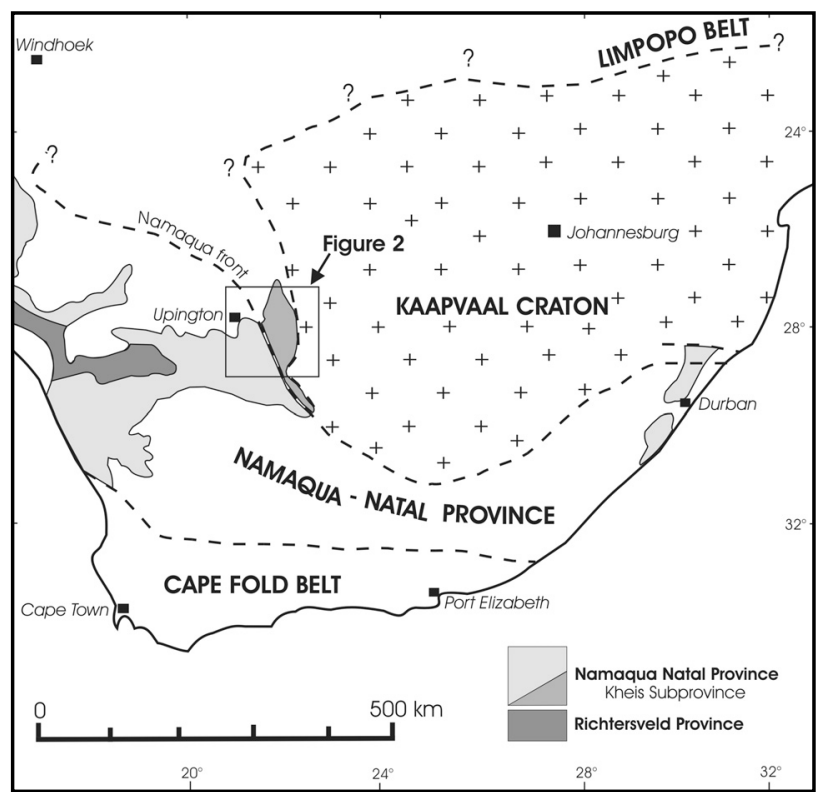

Figure 1. Regional distribution and outcrop areas of the Kibaran orogeny (Namaqua-Natal Province) in southern Africa.

the Olifantshoek and Brulpan successions as Kibaran $(\sim 1.1 \mathrm{Ga})$. In most later published works, however, this deformation was ascribed to an Eburnean $(\sim 1.8 \mathrm{Ga})$ event with Kibaran overprinting present only in the western parts. This interpretation was based largely on an ${ }^{39} \mathrm{Ar} /{ }^{40} \mathrm{Ar}$ age of $1780 \mathrm{Ma}$, obtained on a metavolcanic unit within the Kheis Subprovince. Thus the Kheis "Subprovince" of Hartnady et al. (1985) was a subdivision of their Eburnean Kgalagadi Province which included similarly-aged rocks at Okwa in Botswana and the Lomagundi Belt in Zimbabwe (c.f. Thomas et al., 1994). One implication of this was that the western boundary of the Kaapvaal Craton was shown in many publications to follow the unconformity at the base of the Olifantshoek Supergroup.

Moen (1999) pointed out that the contact between the Olifantshoek and Brulpan successions is tectonic and not conformable as previously thought. Since previous interpretations concerning the depositional and deformational age of the Brulpan Group were based largely on the nature of this contact, he questioned the Eburnean age ascribed to the deformation in the Brulpan Group and put forward stratigraphic and structural evidence suggesting that this unit, which forms the core of the Kheis Subprovince, was deformed and metamorphosed during the Kibaran Namaqua Orogeny. However, no information has to date been available on the basement and provenance of the meta-arenites of the subprovince; in addition available age data are insufficient to constrain their tectonometamorphic history.

The presence of the post-tectonic Koras Group in the western part of the Kheis Subprovince provides an opportunity to accurately determine the upper age limit of the Namaqua Orogeny. Despite many bulk zircon and whole-rock age determinations published in the last two decades, this goal has eluded researchers. At ages commonly between $\sim 1.18$ and $1.1 \mathrm{Ga}$, the volcanic rocks turned out to be older than most of the 1.0 to $1.1 \mathrm{Ga}$ syntectonic granites in the adjacent Gordonia Subprovince. This anomaly was first highlighted by Grobler et al. (1977) and has been a longstanding obstacle in the understanding of the Kheis-Namaqua relationship.

\section{Geology in outline}

As previously defined (Moen 1999) the Kheis Subprovince encompasses the area between the Dabep thrust in the east and the Trooilapspan shear zone in the west (Figure 2). Its lithostratigraphy was extensively described by Moen (1999) and only a brief summary is given here. The Brulpan Group occupies the eastern part of the Kheis Subprovince. It is separated from the Olifantshoek Supergroup by the Dabep fault, a steeply inclined structure that also demarcates the eastern limit of regional greenschist metamorphism. Micaceous quartzite occurs in three localities near the base of the group. Termed the Boegoeberg (not shown on Figure 2), Prynnsberg and Uitdraai Formations, they likely represent different exposures of the same stratigraphic unit. The most extensive unit in the Brulpan Group is schist of the Groblershoop Formation, which overlies these quartzites. A strong bedding-parallel foliation, intrafolial isoclines and gradational lithological contacts are characteristic features of the group, and the metamorphic grade is greenschist facies throughout.

The western part of the Kheis Subprovince consists largely of the Vaalkoppies Group, which extends from the vicinity of the Brakbosch fault to the Trooilapspan shear zone. In contrast to the Brulpan Group, the lower part of the succession (Dagbreek Formation) comprises a varied assemblage of quartzitic to semipelitic rocks. The metamorphic grade rises towards the west so that part of the formation consists of stromatic paragneisses with sillimanite, magnetite and hornblende or pyroxene as common constituents. In the east, in the vicinity of the Brakbosch fault, the upper part of the group (Sultanaoord Formation) forms prominent hills. It consists of several thick, massive and non-micaceous quartzites interbedded with relatively thin units of contorted red schist. Bedding/foliation is generally steep and the sharp lithological contacts lead to the development of rocky cliff faces, as opposed to the Brulpan Group's rounded hills.

The interface between the Brulpan and Vaalkoppies Groups is marked by a branching set of vertical faults described as the Brakbosch-Blauwbospan fault system (Moen, 1999). Between the eastern- and westernmost of these lies the Wilgenhoutsdrif Group, a thick succession of tholeiitic metabasalts, metarhyolites and a variable collection of metasediments ranging from conglomerate to phyllite and carbonates. Serpentinite lenses occur in the mostly sedimentary rocks which comprise the lower part of the succession. The upper part is a threefold cyclical repetition of rhyolite, basaltic rocks and sediments. Despite intense shearing, volcanic textures 


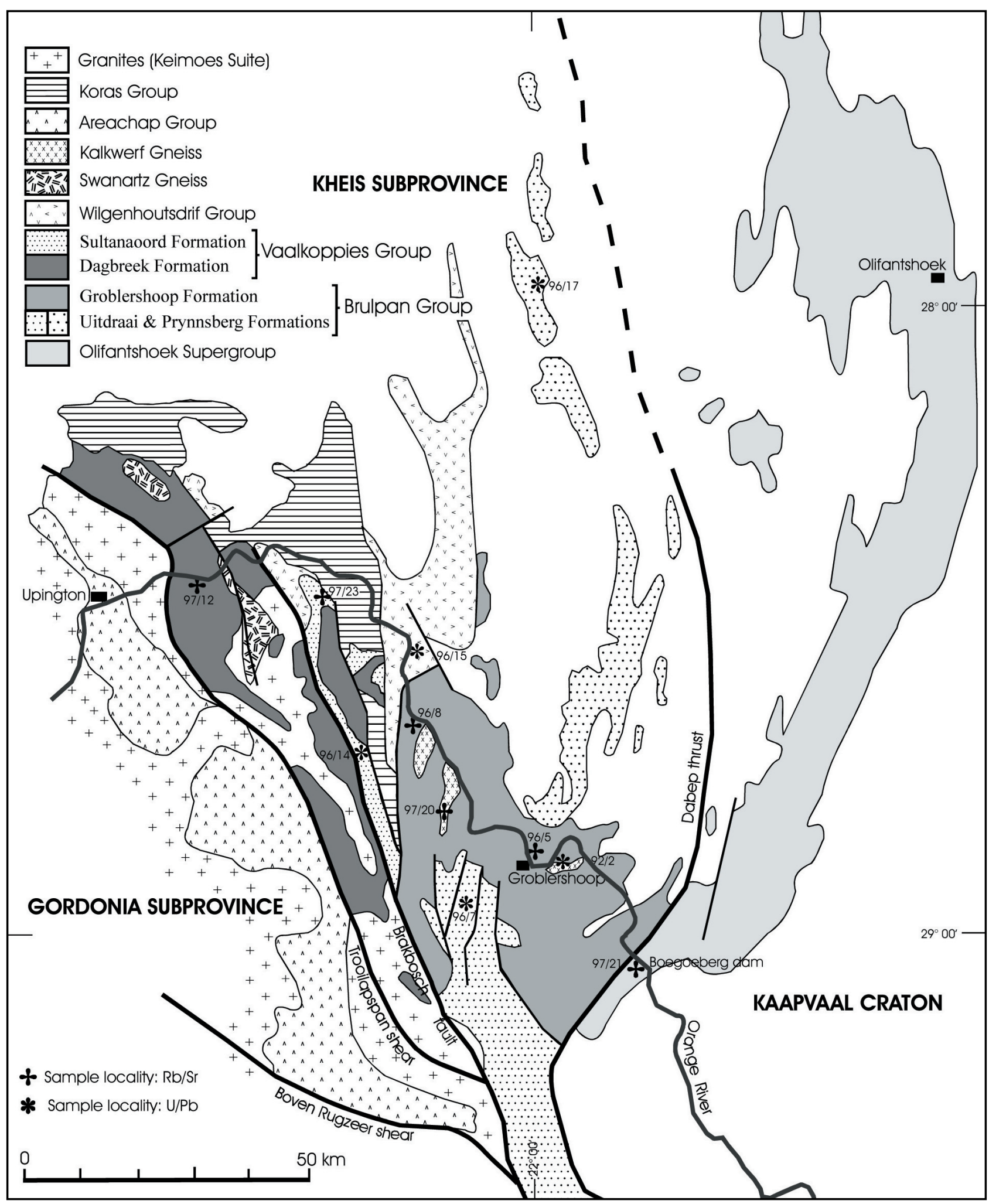

Figure 2. Simplified lithostratigraphy of the eastern margin of the Namaqua Province in the northern Cape Province, showing tectonic subdivisions and geochronological sample localities.

such as phenocrysts, amygdales and pillow structures are remarkably well preserved. The thickness of the succession probably exceeds $5000 \mathrm{~m}$; its top is however not exposed. The Wilgenhoutsdrif Group contains a considerable volume of felsic lava; in the upper part the ratio of acidic to basaltic lavas is approximately $1: 1$.
The conglomerates contain clasts of granite, quartzite and various lithologies scavenged from the group itself. The Wilgenhoutsdrif Group displays the same structural and metamorphic imprint as the adjacent successions. While its basal contact is structurally concordant, it evidently overlies the Brulpan and Vaalkoppies Groups. 
Table 1. Conventional U-Pb and whole-rock age determinations in the Kheis Subprovince. Mb=metabasite, Qp=quartz-feldspar porphyry, Sy=syenite, Gg=granite gneiss, Mig=migmatitic paragneiss (zircon), Q=quartzite (zircon).

\begin{tabular}{|c|c|c|c|c|}
\hline Lithostratigraphic unit & Rock type & Age (Ma) & Method & Reference \\
\hline Wilgenhoutsdrif Group & $\mathrm{Mb}$ & 1030 & $\mathrm{Rb}-\mathrm{Sr}$ & Burger and Coertze, 1975 \\
\hline Wilgenhoutsdrif Group & Qp & 1331 & $\mathrm{~Pb} / \mathrm{Pb}$ & Barton and Burger, 1983 \\
\hline Wilgenhoutsdrif Group & Sy & 1332 & $\mathrm{~Pb} / \mathrm{Pb}$ & Barton and Burger, 1983 \\
\hline Wilgenhoutsdrif Group & Qp & 1336 & $\mathrm{~Pb} / \mathrm{Pb}$ & Barton and Burger, 1983 \\
\hline Wilgenhoutsdrif Group & Qp & 1287 & $\mathrm{~Pb} / \mathrm{Pb}$ & Barton and Burger, 1983 \\
\hline Kalkwerf Gneiss & Gg & 1268 & $\mathrm{U}-\mathrm{Pb}$ & Barton and Burger, 1983 \\
\hline Kalkwerf Gneiss & Gg & 1485 & $\mathrm{U}-\mathrm{Pb}$ & Barton and Burger, 1883 \\
\hline Groblershoop Formation & $\mathrm{Mb}$ & 1049 & $\mathrm{Rb}-\mathrm{Sr}$ & Barton and Burger, 1983 \\
\hline Groblershoop Formation & $\mathrm{Mb}$ & 1780 & $\mathrm{Ar} / \mathrm{Ar}$ & Burger and Coertze, 1975 \\
\hline Dagbreek Formation & Mig & 2100 & $\mathrm{U}-\mathrm{Pb}$ & Barton and Burger, 1983 \\
\hline Uitdraai Formation & Q & 2257 & $\mathrm{U}-\mathrm{Pb}$ & Quoted by Malherbe, 1979 \\
\hline Swanartz Gneiss & Gg & 1368 & $\mathrm{U}-\mathrm{Pb}$ & CGS unpublished data,1993 \\
\hline
\end{tabular}

The Wilgenhoutsdrif and Vaalkoppies Groups are unconformably overlain by the Koras Group. Although this group is spatially restricted to the Kheis Subprovince its unmetamorphosed character sets it apart from other components of the (structural and metamorphic) Kheis Subprovince. Also comprising basalts, felsic lavas and interlayered sediments, it resembles a post-tectonic equivalent of the upper part of the Wilgenhoutsdrif Group. The lavas are however calc-alkaline, there are no pillow structures and syngenetic hydration is a characteristic feature. The sediments are typical red-beds and consist mainly of sandstone and conglomerate. The clast population in the latter indicates a spatially restricted provenance, while older units in the group were scavenged to a considerable degree. Sorting and rounding are often poor and the rudites are thought to represent talus fan deposits which developed along active growth faults. The uppermost sedimentary unit includes a basal conglomerate up to $3000 \mathrm{~m}$ thick, and contains clasts derived from the Kaapvaal Craton. Subvolcanic relatives of the Koras Group are granophyre, gabbronorite, granite and quartz porphyry dykes. While not affected by Namaqua folds, the strata were tilted and faulted during post-depositional brittle vertical faulting.

The Groblershoop Formation is intruded by the Kalkwerf Gneiss, a leucocratic augen gneiss exposed in several outcrops near the Orange River. It displays

Table 2. Samples used in the U-Pb zircon investigation.

\begin{tabular}{llll}
\hline Sample No. & $\begin{array}{l}\text { Lithostratigraphic } \\
\text { unit }\end{array}$ & Lithology & \multicolumn{1}{l}{ Locality } \\
\hline HFM 96/17 & $\begin{array}{l}\text { Prynnsberg } \\
\text { Formation }\end{array}$ & Quartzite & $28^{\circ} 06^{\prime} \mathrm{S}, 22^{\circ} 03^{\prime} \mathrm{E}$ \\
\hline HFM 96/7 & Uitdraai & Quartzite & $28^{\circ} 57^{\prime} \mathrm{S}, 21^{\circ} 53^{\prime} \mathrm{E}$ \\
& Formation & & \\
\hline HFM 96/14 & Sultanaoord & Quartzite & $28^{\circ} 37^{\prime} \mathrm{S}, 21^{\circ} 42^{\prime} \mathrm{E}$ \\
& Formation & & \\
\hline HFM 96/15 & Wilgenhoutsdrif & Rhyolite & $28^{\circ} 34^{\prime} \mathrm{S}, 21^{\circ} 48^{\prime} \mathrm{E}$ \\
& Group & & \\
\hline HFM 92/2 & Kalkwerf Gneiss & Augen gneiss $28^{\circ} 54^{\prime} \mathrm{S}, 22^{\circ} 03^{\prime} \mathrm{E}$ \\
\hline
\end{tabular}

gradational contacts with the surrounding schist and contains concordant inclusions which are difficult to recognise due to felspathisation. Its structural fabric is considered axial planar to the earliest folds in the Kheis Subprovince, and the gneiss is therefore generally accepted to be a pre- or syntectonic intrusion. Further west the more biotite-rich Swanartz Gneiss intrudes the Dagbreek Formation. These two augen gneisses are unusual as the Namaqua Front is dominated by epizonal granitoids of the $\sim 1.1 \mathrm{Ga}$ Keimoes Suite, to which they are clearly not related. Both units have therefore in the past been targeted for geochronology.

\section{Previous geochronological work}

The Eburnean age of the "Kheis Orogeny", as proposed by Stowe (1983) and others, was based largely on a whole-rock ${ }^{39} \mathrm{Ar} /{ }^{40} \mathrm{Ar}$ age of $\sim 1.78 \mathrm{Ga}$, determined on a metavolcanic interlayer in the Groblershoop Formation (Table 1). Whilst the analyst reported it as a minimum age with considerable uncertainty, later publications reported it erroneously as a U-Pb age, thereby affording it unwarranted credence. Conventional (bulk zircon) age determinations on the Kalkwerf Gneiss did however not provide support for the Eburnean theory; the ages obtained rather pointed to an early Namaquan origin, possibly with some sample contamination (Table 1).

Two conventional U-Pb zircon age determinations were obtained on two units in the Wilgenhoutsdrif Group, one on what appears to be a felsic pyroclastic flow and one on an alkaline plug related to the volcanites. Original as well as recalculated ages (Table 1) cluster around $1.33 \mathrm{Ga}$, again providing no support for an Eburnean event in the Kheis. These ages, at the time believed to be too young, proved impossible to repeat by resampling. Proponents of the Eburnean theory either did not accept these ages or regarded the upper part of the Wilgenhoutsdrif Group as a post-Kheis Orogeny deposit (c.f. Stowe, 1986).

Whilst the ages reflected in Table 1 are in broad agreement with the structural and stratigraphic deductions of Moen (1999), large error margins preclude the establishment of a reliable time framework for the 


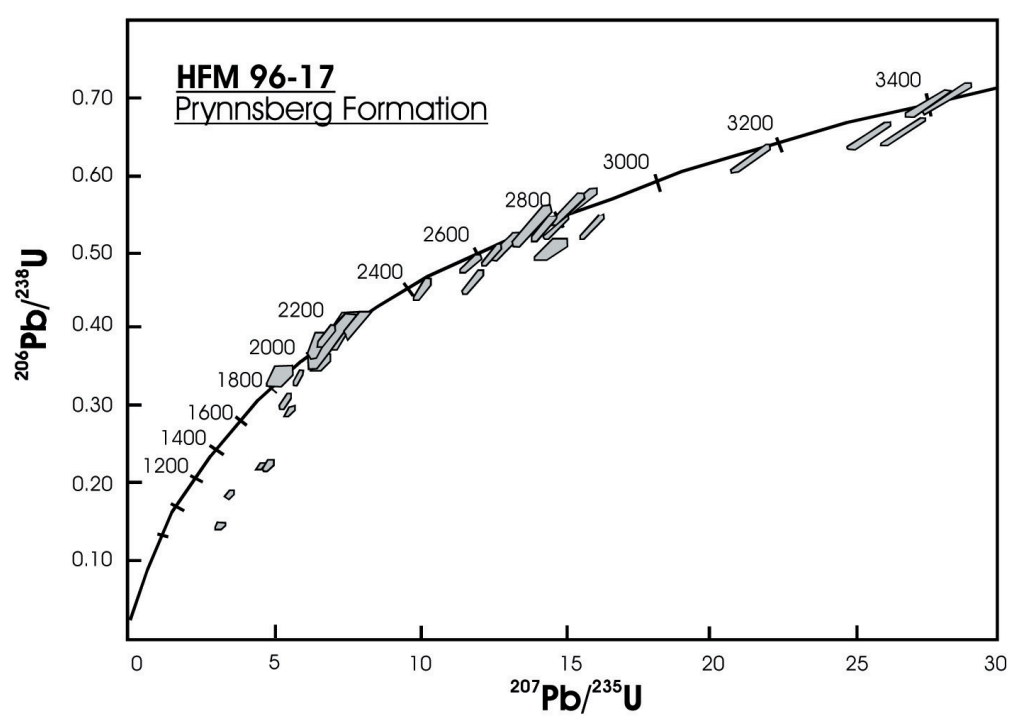

Figure 3. U-Pb concordia diagram of SHRIMP analyses of detrital zircons from the Prynnsberg Formation. Error boxes are one sigma, and the concordia is calibrated in millions of years.

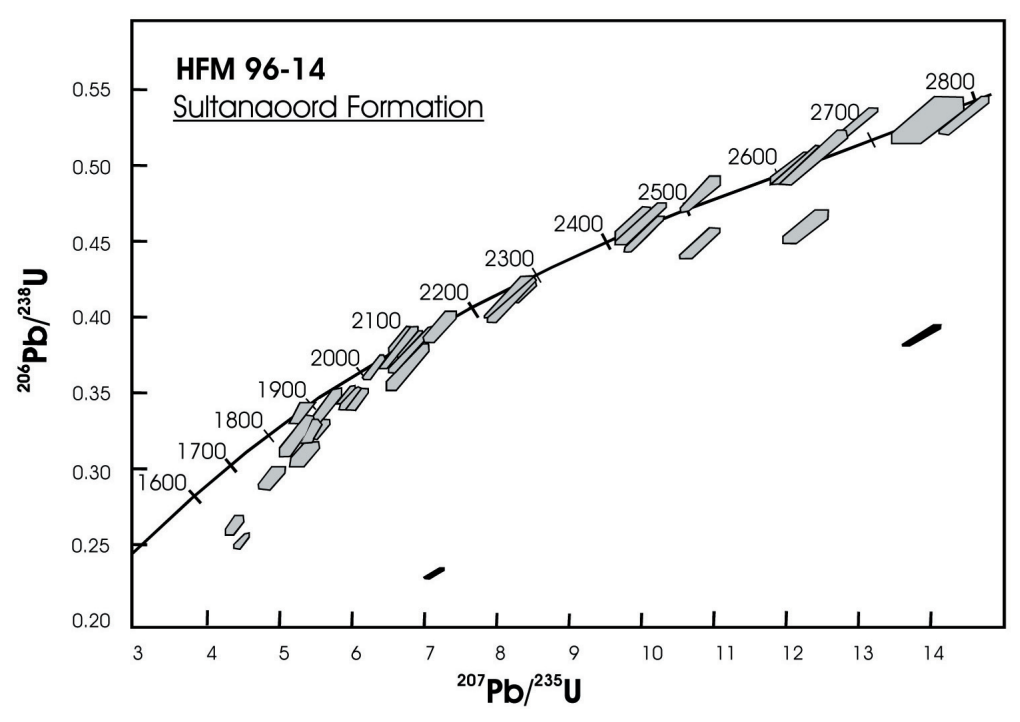

Figure 4. Concordia diagram for SHRIMP U-Pb data for zircons from the Sultanaoord Formation. Error boxes are one sigma, and the concordia is calibrated in millions of years.

apparent "early Namaqua" event and provide few constraints on the age of the Brulpan and Vaalkoppies Groups. In addition they do not address the anomalous relationship between the ages of the Koras Group and the Namaqua Orogeny. Single-grain zircon geochronology was therefore applied to provide acceptable constraints on the geochronological framework of the Kheis Subprovince. This paper reports on the results of several new age determinations on sedimentary, volcanic and plutonic rocks in the Kheis Subprovince. These data allow for a reassessment of the evolution of the Kheis Subprovince, as well as the anomalous age relationship between the "early Namaqua" ages, the age of the Koras Group and the upper age limit of the Namaqua Orogeny.

\section{Approach and sampling procedures}

A threefold approach was employed to obtain the most comprehensive insight into the tectonic development of the area. The Brulpan and Vaalkoppies Groups were investigated by obtaining single-grain $\mathrm{U}-\mathrm{Pb}$ ages on detrital zircons extracted from the Uitdraai, Prynnsberg and Sultanaoord Formations. These ages not only provide a maximum age for the tectono-metamorphic event in the Kheis Subprovince but also for the first time allow an insight into the geochronological make-up of the source area from which these arenites were derived. A lower age constraint on the deformation was defined by obtaining high-precision U-Pb ages on pre- or early tectonic rhyolite of the Wilgenhoutsdrif Group and the Kalkwerf Gneiss, while the upper age limit is provided 


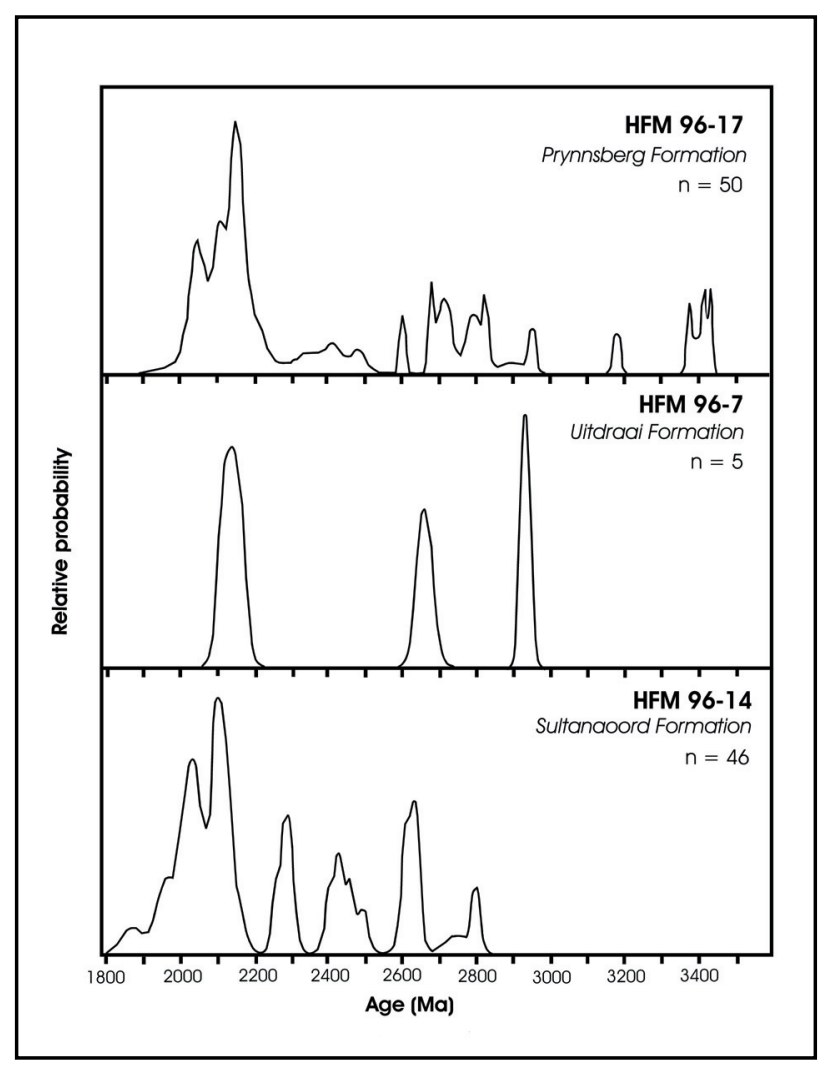

Figure 5. Combined relative probability plots of ${ }^{207} \mathrm{Pd} /{ }^{206} \mathrm{~Pb}$ ages of detrital zircons from three quartzite horizons in the Kheis Subprovince. See text for details.

by the post-tectonic Koras Group. Direct assessment of the age of the foliation-forming event was achieved by obtaining $\mathrm{Rb}-\mathrm{Sr}$ ages on metamorphic muscovites extracted from schistose rocks along a northwest trending line across the entire Kheis Subprovince from the Boegoeberg Dam to just east of Upington (Figure 2).

In selecting samples for detrital zircon analysis, preference was given to rocks displaying small-scale heavy-mineral layers rather than the ubiquitous pure, glassy quartzites. All samples were $>10 \mathrm{~kg}$. The Kalkwerf Gneiss is generally deeply weathered, but a sample could be obtained by percussion drilling in an abandoned quarry. The Wilgenhoutsdrif Group contains three acidic lava units; the middle layer returned a conventional U-Pb age (see Table 1) but this unit, as well as the upper unit, did not yield any useful zircons during several later samplings. The lower unit was therefore selected, and a composite $4 \mathrm{~kg}$ sample was obtained from the severely jointed outcrop. Details are given in Table 2 and sample positions are indicated on Figure 2.

All samples were crushed and sieved at the Radiogenic Isotope Laboratory of the Council for Geoscience in Pretoria. Zircon-bearing concentrates were obtained by means of a specially adapted Wilfley table, and further concentration was achieved by magnetic and heavy-liquid separation. Selected zircon grains were mounted and analysed by Prise Radiogenic
Isotope Services at the Australian National University. Muscovites were extracted from crushed and sieved powder by electrostatic separation and analysed at the Council for Geoscience.

\section{Results}

The results of the detrital zircon studies are graphically summarised in Figure 5 and the data tables are lodged with the Council for Geoscience (Upington Office). As expected, zircons from the Brulpan Group (Uitdraai and Prynnsberg Formations) and the Vaalkoppies Group (Sultanaoord Formation) were highly rounded and abraded. Those from the first two formations also display significant variation in size, $U$ and Th content and transparency. Clear grains with low $\mathrm{U}$ concentrations are probably remnants of metamorphic zircons. The Sultanaoord sample was considerably more mature, and the extracted zircons consequently show a more restricted size variation. None of the zircons investigated showed Namaqua-aged overgrowths.

A total of fifty different zircons from the Prynnsberg Formation were analysed (Figure 3). The majority of the data plot between 2.0 and $2.2 \mathrm{Ga}$, with a number of variably discordant analyses falling on a poorly defined discordia showing evidence of severe Pb-loss. Some of the zircons have extremely low (less than $10 \mathrm{ppm}) \mathrm{U}$ and Th contents. One such grain yielded the youngest concordant $207 \mathrm{~Pb} / 206 \mathrm{~Pb}$ age of $1814 \pm 123$ Ma. Unfortunately, due to a comparatively large common lead correction, this age is imprecise and therefore not a reliable time marker.

A Wetherill concordia plot of forty-six analyses from the Sultanaoord Formation (Figure 4) shows that the majority of the analyses are concordant or nearly so, with $207 \mathrm{~Pb} / 206 \mathrm{~Pb}$ ages showing a range of approximately $1.0 \mathrm{Ga}$. The youngest concordant analysis gives a $207 \mathrm{~Pb} / 206 \mathrm{~Pb}$ age of $1874 \pm 24 \mathrm{Ma}$, and the oldest gives $2805 \pm 9 \mathrm{Ma}$.

Only five analyses of zircons from the Uitdraai Formation were analysed, as initial analyses indicated a similarity to the Prynnsberg Formation and field evidence indicates that these two formations are probably stratigraphically equivalent.

The three data sets are shown in a combined relative probability plot in Figure 5. Only data less than $10 \%$ discordant are included in these plots, minimising the effects of non-zero age Pb-loss on the apparent $207 \mathrm{~Pb} / 206 \mathrm{~Pb}$ ages.

The age of the Wilgenhoutsdrif Group was determined on zircons extracted from an acid lava known as the Lower Rhyolite (Moen, 1988) a unit not previously sampled for geochronology. As in previous samples, the zircons were small, clear and colourless to light yellow. They displayed a characteristic bladed or tabular form and although many were fragmented (probably in the crushing process), many euhedral crystal faces were preserved. The crystal forms, compositional zoning and elongate "holes" are features 


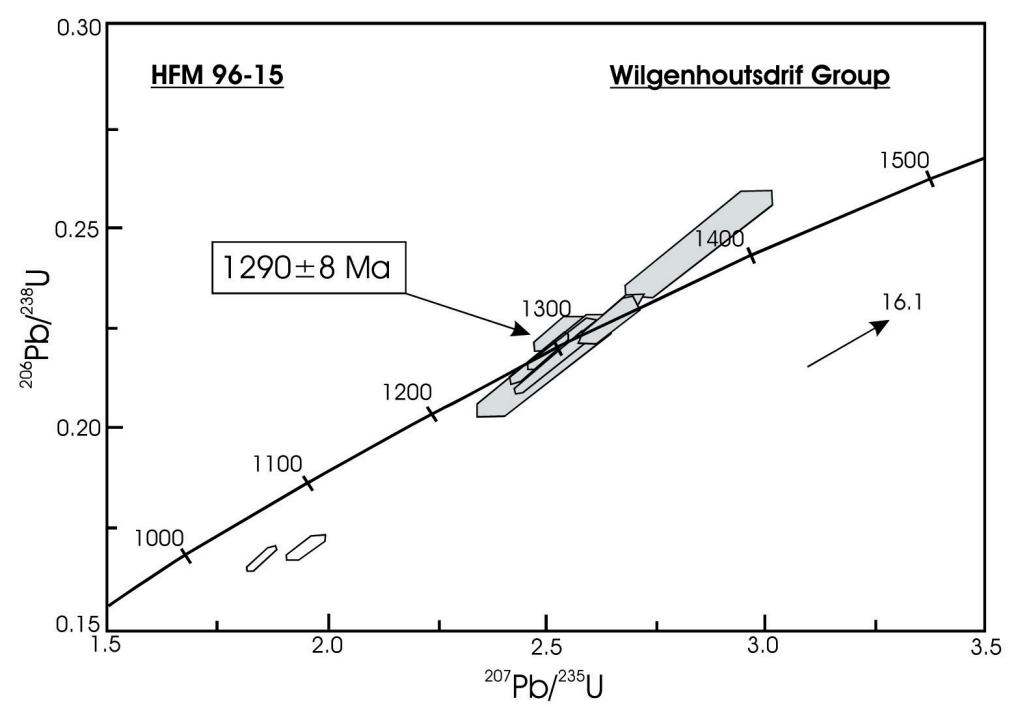

Figure 6. $\mathrm{U}-\mathrm{Pb}$ concordia plot of data from a rhyolite in the Wilgenhoutsdrif Group. The weighted mean ${ }^{207} \mathrm{~Pb} /{ }^{206} \mathrm{~Pb}$ age of $1290 \pm 8 \mathrm{Ma}$ is calculated from the concordant group of data shown in the filled error boxes.

commonly observed in volcanic rocks. No Namaquaaged (1.1 to $1.2 \mathrm{Ga}$ ) overgrowths were found on any of the zircon grains.

Two highly discordant analyses reflect effects of radiogenic $\mathrm{Pb}$ loss and are excluded in the age calculation. The inherited grain (16.1) gives a ${ }^{207} \mathrm{~Pb} /{ }^{206} \mathrm{~Pb}$ age of $2702 \pm 6 \mathrm{Ma}$ and may be related to similarly-aged granites in the Marydale area. The remainder of the SHRIMP data plot as a concordant group (Figure 6), yielding a weighted mean age of $1290 \pm 8 \mathrm{Ma}$.

The Kalkwerf Gneiss yielded an abundant crop of euhedral zircons. The typical zircon is stubby, strongly zoned and only lightly coloured. Some have metamict zones, indicating high radioactive element concentrations. Excluding three highly discordant analyses, the age calculated from a group of concordant and near-concordant analyses (Figure 7) is $1293 \pm$ 9 Ma. This is interpreted as the crystallisation age. No xenocrystic grains were encountered.

Muscovite was separated from six samples taken across the Kheis Subprovince and including one from the on-craton Olifantshoek Supergroup. The muscovites thus range from non-metamorphic (sample 97/21) through greenschist grade to upper amphibolite (sample 97/12). The calculated $\mathrm{Rb}-\mathrm{Sr}$ ages are tabulated in Table 3. Despite the low error margins, the ages are not necessarily reliable in geological terms as they are very dependent on the initial ratio, which was taken as 0.72 . Not enough whole-rock and mineral work has to date been done in the area to determine a reliable initial ratio. Four out of five samples from the Kheis Subprovince indicate that the regional metamorphism took place at around $1165 \mathrm{Ma}$. Since metamorphism in the Olifantshoek Supergroup is very low grade, the significantly older age in that unit is probably a reflection of the fact that most of the mica recovered from this sample is detrital. There is no ready explanation for the aberrant age of the Sultanaoord sample.

\section{Discussion and conclusions}

Inspection of the age spectra of detrital zircons from the Kheis Subprovince reveals some marked differences, the significance of which is unclear. There is however sufficient general agreement to conclude that at least two of the different lithological units shared a common provenance. While not all the detrital zircon ages can be related to plutonic events on the Kaapvaal Craton, the prominent peaks at $\sim 2.1,2.8$ to $2.7,3.2$ and $3.4 \mathrm{Ga}$ (Figure 3) indicate that the Prynnsberg Formation, and probably also the Uitdraai Formation, were derived from the east. Zircons from the $\sim 2.9 \mathrm{Ga}$ old basement at Marydale occur in the nearby Uitdraai Formation, but are absent from the Sultanaoord Formation. The age spectra show conclusively that all three units, i.e. all the arenitic

Table 3. Rb-Sr muscovite ages across the Kheis Subprovince.

\begin{tabular}{llll}
\hline Sample No. & Lithostratigraphic unit & Lithology & Age \\
\hline HFM 97/21 & Olifantshoek Supergroup & Grey quartzite & $1572 \pm 27$ \\
HFM 96/5 & Groblershoop Formation & Quartz-muscovite schist & $1183 \pm 18$ \\
HFM 96/8 & Groblershoop Formation & Schistose quartzite & $1170 \pm 19$ \\
HFM 97/20 & Kalkwerf Gneiss & Granite gneiss & $1161 \pm 18$ \\
HFM $97 / 23$ & Sultanaoord Formation & Massive grey quartzite & $1390 \pm 23$ \\
HFM $97 / 12$ & Dagbreek Formation & Quartz-rich granoblastite & $1144 \pm 18$ \\
\hline
\end{tabular}




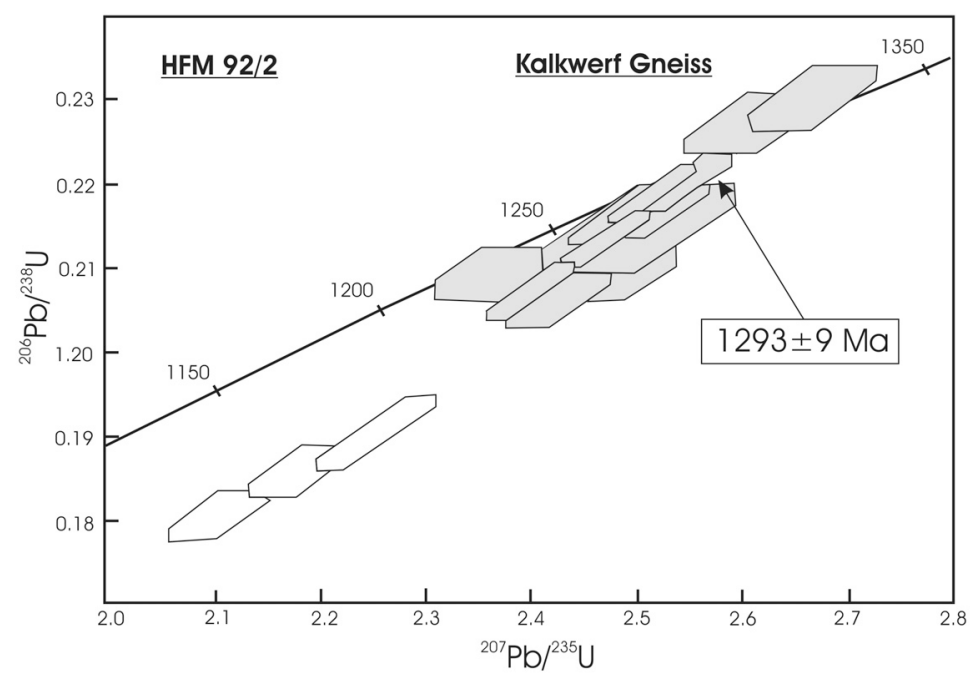

Figure 7. Concordia diagram for SHRIMP U-Pb data for zircons from the Kalkwerf Gneiss. The weight mean ${ }^{207} \mathrm{~Pb} /{ }^{206} \mathrm{~Pb}$ age is calculated from the filled error boxes.

rocks making up the Kheis Subprovince, are younger than $\sim 1.8 \mathrm{Ga}$.

According to Drennan et al. (1990) the crystalline basement west of the so-called "Colesberg trend" (i.e. the western part of the Kaapvaal Craton) contains some $\sim 3.25 \mathrm{Ga}$-old granitoids but in general the cratonic basement is younger than $\sim 3.1 \mathrm{Ga}$ (e.g. Cornell and Barton, 1979). In addition, the basement adjacent to the Kheis Subprovince was buried under a thick blanket of Vaalian carbonate and iron formation deposits, and contribution of detritals from this part of the craton is unlikely. Possible source rocks of the $\sim 3.4 \mathrm{Ga}$ zircons in the Prynnsberg Formation are restricted to the northern and north-eastern parts of the craton, implying a considerable transport distance since the clastic detritus likely followed a circuitous route along the edge of the craton. The zircon age spectra suggest that arenites of the Brulpan Group, like those of the Olifantshoek Supergroup, were derived from the craton. The Brulpan Group thus postdates the Olifantshoek Supergroup. In the absence of comparable data on the latter, the possibility that Kheis Subprovince arenites came from a completely different source can however not be dismissed. The age and character of the basement underlying the Kheis Subprovince supracrustals is as yet unknown. No evidence for the presence of rocks comparable to the $\sim 2.9$ Ga granitic basement exposed at Marydale and Prieska was found during the present study, and no information on the Sm-Nd isotopic character of the Wilgenhoutsdrif and Koras lavas is as yet available.

The Sultanaoord Formation differs considerably from the other two arenite formations. The maxima at 2.3 and 2.4 to $2.5 \mathrm{Ga}$ have no apparent counterparts in the Brulpan Group. Moreover, no igneous activity is known to have taken place on the craton during these times. Although the 2.2 to $1.9 \mathrm{Ga}$ maximum corresponds to that of the Prynnsberg Formation, the range of this maximum is too great for the Bushveld igneous event alone and the provenance of this formation is speculative.

An upper age limit on the age of the Brulpan and Vaalkoppies Groups is set by the Wilgenhoutsdrif Group and the Kalkwerf Gneiss. These units are demonstrably younger than the arenites; the former unconformably overlies them and the latter is intrusive into the Brulpan Group (Moen, 1999). Previous attempts to date these important time markers returned inaccurate but unexpectedly young results: the Kalkwerf Gneiss ranging from 1200 to $1485 \mathrm{Ma}$ and the Wilgenhoutsdrif at $\sim 1.3 \mathrm{Ga}$ (see Table 1). The precise ages of $1290 \mathrm{Ma}$ for both these units reported here show that the previously obtained ages, though inaccurate, were not far off the mark. The depositional age of the Brulpan and Vaalkoppies Groups thus lies between 1.3 and $1.8 \mathrm{Ga}$. The absence of $<1.8 \mathrm{Ga}$ zircons must however not be seen as proof that the controversial OlifantshoekBrulpan contact (Moen, 1999) is conformable. If indeed the Brulpan Group was derived from the Kaapvaal Craton, it must be borne in mind that, apart from small alkaline complexes, no igneous activity took place there during the interval 1.8 to $1.3 \mathrm{Ga}$, and this $500 \mathrm{Ma}$ gap can in all probability not be narrowed down by means of zircon dating. The two arenite successions may have been deposited anywhere in this time interval.

The Wilgenhoutsdrif age not only supports the findings of Moen (1988) and others that this volcanosedimentary succession unconformably overlies the Brulpan and Vaalkoppies Groups, but also has implications for the tectonic development of the Kheis Subprovince as a whole. The pre- or syntectonic character of the Kalkwerf Gneiss was discussed by Moen (1999), who reported that all the structural elements recognised in the Brulpan and Vaalkoppies Groups are also present in the Wilgenhoutsdrif Group. The new age 
determinations thus confirm that the Palaeoproterozoic $(\sim 1.8 \mathrm{Ga})$ "Kheis Orogeny" of Hartnady et al. (1985) and Stowe (1986) does not exist in the Kheis Subprovince as defined in Moen (1999). The muscovite ages further show that the recumbent isoclinal tectonic fabric and associated east-verging thrusts that characterise the Kheis Subprovince formed $\sim 1.2 \mathrm{Ga}$ ago and are thus clearly not related to an Eburnean orogeny. Structurally the Kheis Subprovince developed as a precursor to the Mesoproterozoic Namaqua Orogeny, and the Kheis Subprovince is thus a tectonostratigraphic subunit of the Namaqua Province.

The deformation in the adjacent Olifantshoek Supergroup is here also tentatively regarded as Namaquan in age. These west-verging, low intensity folds contrast sharply with the recumbent, isoclinal structural style in the Kheis Subprovince. Nevertheless it seems unlikely that the early Namaquan deformation recognised in the latter should have no effect east of the Dabep thrust. The recognition of an Eburnean orogeny in the Olifantshoek area by Cornell et al. (1998) was based amongst others on the relationship between structures and metamorphism, and it is believed that their conclusions in this regard may not be valid.

Some aspects of the geochronology of the eastern part of the Namaqua Province warrant further investigation. As a probable back-arc succession the Wilgenhoutsdrif Group accumulated under tensional conditions, possibly transpression. The potassic Kalkwerf Gneiss and other minor alkalic intrusions were probably associated with this period of alternating mafic and acidic volcanism; in a similar scenario the K-rich Blauwbosch Granite and other plutonites are associated with the Koras Group (Moen, 1987). The Kalkwerf Gneiss is therefore strictly a pre-tectonic plutonite. The Wilgenhoutsdrif Group and Kalkwerf Gneiss ages constrain the Namaqua Orogeny in the Kheis Subprovince to somewhere between $\sim 1.3$ and $\sim 1.17 \mathrm{Ga}$, significantly older than the range of $\sim 1.2$ to $\sim 1.0$ Ga generally ascribed to the orogeny in the adjacent Gordonia Subprovince. That early plutonism may have preceded the main orogenic event is also suggested by the Swanartz Gneiss (1368 \pm 17 Ma, Table 1), a biotite augen gneiss intrusive into the Vaalkoppies Group in the western part of the Kheis Subprovince. This is however a conventional bulk zircon age and not reliable Thomas et al. (1994) pointed out that the "Kibaran Orogeny" in its type area in central Africa came to an end $\sim 1.25 \mathrm{Ga}$ ago, but the term has been widely applied to include subsequent tectono-metamorphic activity up to $\sim 1.0 \mathrm{Ga}$. The $\sim 1.3$ to $\sim 1.2 \mathrm{Ga}$-old episode of metamorphism and associated volcanism preserved in the Kheis Subprovince is thus comparable to the Kibaran of central Africa. It is noteworthy that the Grenville Province also comprises two similar subdivisions, namely Ottawan $(\sim 1.1$ to $\sim 1.0 \mathrm{Ga})$ and Elsevirian $(\sim 1.3$ to $\sim 1.15 \mathrm{Ga}$ ).

In comparing the above results with the adjacent Gordonia Subprovince and Bushmanland, it is of interest to note that the Namaqua Orogeny comprises two distinct episodes which, in the western Gordonia Subprovince, were dated at $\sim 1.21$ and $\sim 1.1 \mathrm{Ga}$ respectively (Moen and Toogood, 2007). The first is associated with the highest metamorphic grades while the second is evidenced by mineralogical adjustments in metapelites and widespread granite emplacement. Both were foliation-forming events, the younger mostly obliterating the older fabrics. Only one episode is present east of the Trooilapspan shear zone, and the 1100 event is clearly not in evidence there. While it is tempting to correlate the older Namaqua event with the deformation in the Kheis Subprovince, comparable data from Bushmanland are scant and none are available in the Upington area. No conclusions can therefore be made concerning distribution and possible age variations in the regional metamorphic pattern.

While the above evidence provides information on the tectonic history of the Kheis Subprovince and the age of its supracrustals, there is still little information on the age and composition of its (crystalline?) basement. Available data suggest that the western part of the Kaapvaal Craton consists of $\sim 3.2$ to $\sim 3.0$ Ga granitoids, but despite the exposure of such rocks at Marydale, there is no evidence that Swazian rocks occur west of the Dabep thrust. Ages around $1.8 \mathrm{Ga}$ have however been recorded from granitoids just west of the edge of the Kaapvaal Craton south of Marydale, and similarlyaged xenocrysts have been found in sediments of the Koras Group (D.H. Cornell, personal communication, 2005). There is thus some evidence pointing to an $\sim 1.8 \mathrm{Ga}$ old basement, but more directed research is needed to verify this. To this end a Sm-Nd study of the acid lavas of the Wilgenhoutsdrif and Koras Groups might reveal information on the age of the lower crust that was the source for these voluminous lavas.

In the western part of the Kheis Subprovince, the post-tectonic Koras Group ( 1.17 Ga, Gutzmer et al., 2000) unconformably overlies rocks previously thought to reflect the $\sim 1.1$ to $\sim 1.0$ Ga Namaqua Orogeny with an angular unconformity. Numerous conventional and a few single-grain $\mathrm{U}-\mathrm{Pb}$ age determinations on granites of the adjacent Keimoes Suite have consistently returned ages around 1.1 to $1.0 \mathrm{Ga}$, and the apparent age reversal across the perceived unconformity has remained an unresolved conundrum despite several investigations during the last forty years. The geochronological results presented above, in conjunction with the recognition of the Trooilapspan shear zone as a terrane boundary, show for the first time that this age reversal does in fact not exist in the field. This is because the Koras Group overlies rocks of the Kheis Subprovince exclusively; nowhere does it physically overlie $\sim 1.0 \mathrm{Ga}$ granitoids of the Keimoes Suite, despite their close proximity. The great predominance of meta-arenites and the paucity of datable crystalline rocks have in the past prevented researchers from dating rocks that actually underlie the volcano-sedimentary Koras Group, and the early Kibaran age of the Kheis metamorphism therefore 
went unnoticed. In fact the < 1.17 Ga old Koras Group overlies rocks which were deformed during a tectonometamorphic event bracketed between $\sim 1.3$ and $\sim 1.2$ $\mathrm{Ga}$, and not $\sim 1.1 \mathrm{Ga}$ or younger, as previously thought. Furthermore the age pattern in the Kheis Subprovince allows for the significant period of erosion that must have preceded deposition of the Koras Group.

It remains to be explained how the $\sim 1.3-$ to $\sim 1.2 \mathrm{Ga}$ tectono-metamorphic terrane of the Kheis Subprovince came to be juxtaposed to the $\sim 1.2$ to $\sim 1.0$ Ga Gordonia Subprovince. While the Trooilapspan shear zone was recognised previously, its importance as a fundamental terrane boundary was not realised. This structure not only delimits the eastern boundary of the $\sim 1.3 \mathrm{Ga}$ Areachap Group (Cornell et al., 1990) but at the same time forms the western limit of the lithologies that typify the Kheis Subprovince. While granites of the Keimoes Suite occur to the east of it, none of the Korannaland Group's lithologies are to be found there. The shear zone lies in the "steep zone", characterised by tight folding and intense, near-vertical foliation. Due to strong retrograde alteration in the otherwise high-grade paragneisses and rocks associated with the Areachap Group, the shear zone is poorly exposed and this hampers efforts to determine its translation vectors. It is suggested that the Trooilapspan shear zone has significant lateral as well as vertical components, which may have been responsible for the present configuration of the pre-tectonic successions in the two subprovinces. While the regional kinematics of major lineaments in the Namaqua front area are generally thought to be rightlateral, the kinematics of the nearby Brakbosch fault cannot be determined with confidence and the Boven Rugzeer shear zone displays left-lateral displacement exceeding $70 \mathrm{~km}$. It is therefore thought that the early structural-metamorphic event preserved in the Kheis Subprovince and dated at between 1.3 and $1.2 \mathrm{Ga}$ took place before the Trooilapspan shear zone and associated structures brought the subprovinces to their present configuration.

\section{Acknowledgements}

The authors wish to thank Bruce Eglington and staff of the Isotope Section at the Council for Geoscience for handling the mineral separation and Rb-Sr analyses. The helpful and constructive comments of the referees, Bob Thomas and Alex Kisters, are gratefully acknowledged.

\section{References}

Blignault, H.J., Jackson, M.P.A., Beukes G.J. and Toogood, D.J. (1974). The Namaqua tectonic province in South West Africa. In: A. Kröner, (Editor). Contributions to the Precambrian geology of southern Africa. Bulletin, Precambrian Research Unit, University of Cape Town, South Africa, 15, 29-48

Botha, B.J.V., Grobler, N.J., Linström, W. and Smit, C.A. 1977. Major structural features of the area between the Langeberg range and Kenhardt, Northern Cape Province. Transactions of the Geological Society of South Africa,
80, 101-110

Barton, E.S. and Burger, A.J. (1983). Reconnaissance isotopic investigations in the Namaqua Mobile Belt and implications for Proterozoic crustal evolution. In: B.J.V. Botha, (Editor). Namaqualand Metamorphic Complex. Special Publication of the Geological Society of South Africa, 10, 274pp.

Cornell, D.H., Armstrong, R.A. and Walraven, F. (1998). Geochronology of the Hartley Formation, South Africa: constraints on the Kheis Tectogenesis and the Kaapvaal Craton's earliest Wilson cycle. Journal of African Earth Science, 26, 5-27.

Cornell, D.H. and Barton, E.S. (1979). Age of the Marydale Group Banded iron-formation by the $\mathrm{Pb}-\mathrm{Pb}$ method. Extended Abstracts, 18th Geocongress of the Geological Society of South Africa, 111-114.

Cornell, D.H., Kröner, A., Humphreys, H. and Griffin, G. (1990). Age and origin of the polymetamorphosed Copperton Formation, Namaqua-Natal Province, determined by single-grain zircon $\mathrm{Pb}-\mathrm{Pb}$ dating. South African Journal of Geology, 93, 709-716.

De Beer, J.H. and Meyer, R. (1984). Geophysical characteristics of the Namaqua-Natal Belt and its boundaries, South Africa. Journal of Geodynamics 1, 473-495.

Drennan, G.R., Robb, L.J., Meyer, F.M., Armstrong, R.A. and De Bruijn, H. (1990). The nature of the Archaean basement in the hinterland of the Witwatersrand Basin: II. A crustal profile west of the Welkom Goldfield and comparisons with the Vredefort crustal profile. South African Journal of Geology, 93, 41-53.

Du Plessis, A.J. and Thomas, R.J. (1991). Discussion on the Beattie set of anomalies. Extended Abstracts, Second Annual Technical Meeting of the South African Geophysical Association, Pretoria, South Africa, 57-59.

Grobler, N.J., Botha, B.J.V. and Smit, C.A. (1977). The tectonic setting of the Koras Group. Transactions of the Geological Society of South Africa, 80, $167-175$.

Gutzmer, J., Beukes, N.J., Pickard, A. and Barley, M.E. (2000). 1170 Ma SHRIMP age for the Koras Group bimodal volcanism, Northern Cape Province. South African Journal of Geology, 103, 32-37.

Hartnady, C.J.H., Joubert, P. and Stowe, C.W. (1985). Proterozoic crustal evolution in southwestern Africa. Episodes, 8, 236-244.

Matthews, P.E. (1972). Possible Precambrian obduction and plate tectonics in southeastern Africa. Nature, 240, 37-39.

Moen, H.F.G. (1987). The Koras Group and related intrusives north of Upington: a reinvestigation. Bulletin of the Geological Survey of South Africa, 85, 20pp.

Moen, H.F.G. (1988). Petrology of the Wilgenhoutsdrif Group. Bulletin of the Geological Survey of South Africa, 89, 37pp.

Moen, H.F.G. (1999). The Kheis Tectonic Subprovince, southern Africa: a lithostratigraphic perspective. South African Journal of Geology, 102, $27-42$.

Moen, H.F.G. and Toogood, D.J. (2007). The geology of the Onseepkans area. Explanation: Sheet 2918 Onseepkans, 1:250 O0O. Council for Geoscience, South Africa 101pp.

Stowe, C.W. (1983). The Upington Geotraverse and its implications for Craton Margin Tectonics. In: B.J.V. Botha, (Editor). Namaqualand Metamorphic Complex. Special Publication of the Geological Society of South Africa, 10, 147-171.

Stowe, C.W. (1986). Synthesis and interpretation of structures along the north-eastern boundary of the Namaqua Tectonic Province, South Africa. Transactions of the Geological Society of South Africa, 89, 185-198.

Thomas, R.J., Agenbacht, A.L.D., Cornell, D.H. and Moore, J.M. (1994). The Kibaran of southern Africa: Tectonic evolution and metallogeny. Ore Geology Reviews, 9, 131-160.

Vajner, V. (1974a). Crustal evolution of the Namaqua Mobile Belt and its foreland in parts of the Northern Cape. In: A. Kröner, (Editor). Contributions to the Precambrian geology of southern Africa. Bulletin, Precambrian Research Unit, University of Cape Town, South Africa, 15, 1-15.

Vajner, V., (1974b). The tectonic development of the Namaqua Mobile Belt and its Foreland in parts of the Northern Cape. Bulletin, Precambrian Research Unit, University of Cape Town, South Africa, 14, 201pp.

Editorial handling: L. D. Ashwal 